\title{
Mutations of follicle-stimulating hormone and its receptor; effects on gonadal function
}

\author{
Ilpo T Huhtaniemi and Kristiina Aittomäki ${ }^{1}$ \\ Department of Physiology, University of Turku, 20520 Turku, Finland and ${ }^{1}$ Department of Medical Genetics, University of Helsinki, \\ 00290 Helsinki, Finland
}

(Correspondence should be addressed to I T Huhtaniemi, Department of Physiology, University of Turku, Kiinamyllynkatu 10 , 20520 Turku, Finland)

\begin{abstract}
The physiological functions of the two gonadotropins, follicle-stimulating hormone (FSH) and luteinizing hormone (LH), are quite well known in both males and females. Nevertheless, the recent unraveling of structures of the gonadotropin and gonadotropin receptor genes has provided us with tools to obtain completely new information on the functions of these hormones at the molecular level. Several gain- and loss-of-function mutations of these genes have been discovered in humans, and the first knock-out experiments with these genes in the mouse have been recently published. The purpose of the present review is to describe the current state of knowledge on human mutations of FSH and its receptor, as well as on relevant animal models.
\end{abstract}

European Journal of Endocrinology 138 473-481

\section{Introduction}

Of the two gonadotropins, follicle-stimulating hormone (FSH) and luteinizing hormone (LH), FSH can be considered more elusive, whereas the functions of $\mathrm{LH}$ are quite straightforward and well understood. In the ovary, the latter hormone stimulates theca cell androgen production, triggers ovulation and granulosa cell luteinization, and maintains progesterone production of the corpus luteum. In the testis it is the key stimulus of Leydig cell androgen production. FSH is known to play a role in the ovary in follicular maturation and maintenance of granulosa cell estrogen production, and in the testis it is proposed to participate in the regulation of spermatogenesis. However, until very recently, there has been uncertainty about the specific stages of follicular maturation that are FSH dependent, as well as about the specific requirements of FSH for spermatogenesis. In studies on gonadotropin action, it is almost a rule that everything related to FSH is much more difficult than to $\mathrm{LH}$, and therefore our knowledge of FSH functions lags considerably behind that of LH.

Both gonadotropin molecules consist of two glycoprotein subunits coupled through non-covalent bonds $(1-3)$. One of them is the $\alpha$-subunit, which is common to $\mathrm{LH}, \mathrm{FSH}$, thyroid-stimulating hormone (TSH) and chorionic gonadotropin (CG), and the other is the hormone-specific $\beta$-subunit. A single gene encodes both the common $\alpha$-subunit and the $\operatorname{FSH} \beta$ chain (Fig. 1).
FSH is synthesized in pituitary gonadotrope cells, and, during its synthesis, two N-linked carbohydrate side chains are attached to both of its subunits (Fig. 1). The carbohydrates form about $20 \%$ of the mass of the $33000 \mathrm{kDa}$ FSH molecule. The synthesis and secretion of FSH is partly under the positive control of the hypothalamic gonadotropin-releasing hormone (GnRH), but gonadal activin/inhibin peptides and steroid hormones also participate in the regulation of FSH secretion. As the result of GnRH action, FSH is secreted in a similar pulsatile fashion to LH, but the pulses are less discrete than with $\mathrm{LH}$, because of the longer circulatory half-life of FSH which, in turn, is due to differences in the number and composition of its carbohydrate side chains. The gonadotropins appear in the circulation as a mixture of microheterogeneous isoforms, each with varying composition of the carbohydrate side chains and intrinsic bioactivity (4). Some results indicate that the isoform composition of serum FSH is hormone-dependent and varies in physiological and pathophysiological conditions, but the real importance of this phenomenon remains obscure.

The FSH receptor $(\mathrm{R})$ forms, together with those of LH and TSH, a subclass of G-protein-associated seven times plasma membrane-spanning receptors. They have exceptionally long extracellular domain, constituting about $50 \%$ of the mature receptor protein $(5,6)$. LHR of most mammalian species consists of 11 exons, and those of FSH and TSH of 10 exons, and in each case the 

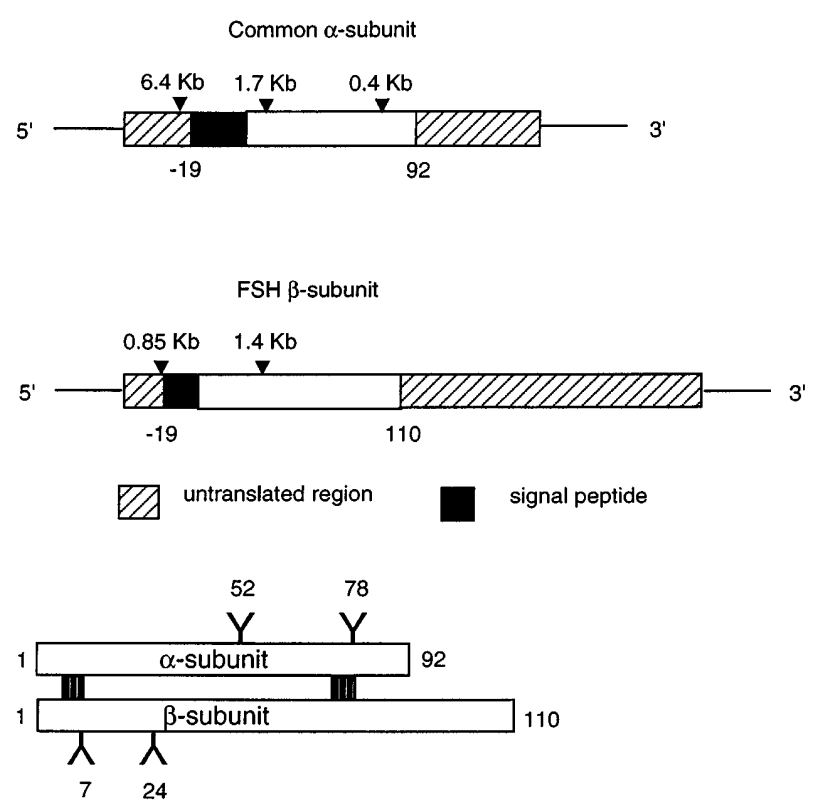

Figure 1 Schematic representation of structures of the common $\alpha$ subunit and $\mathrm{FSH} \beta$ genes (upper panel) and of FSH protein (lower panel). The symbols ' $Y$ ' in the lower panel mark the approximate positions of the $\mathrm{N}$-linked carbohydrate side chains in the FSH molecule $(1,3)$

last exon encodes the entire transmembrane and intracellular domain of the receptor (7, 8; Fig. 2). The molecular size of the FSHR is about $100 \mathrm{kDa}$. The level of gonadotropin receptor gene expression is relatively low, and the number of FSHRs per granulosa/Sertoli cell is only in the thousands. The main second messenger that mediates gonadotropin action (both LH and FSH) is cAMP, but $\mathrm{Ca}^{2+}$ fluxes and inositol trisphosphate turnover are also involved in this process. The importance of the latter pathways in the physiological action of gonadotropin remains obscure. One feature of the gonadotropin receptor genes is the multiple forms of splice variants of their mRNA, but the physiological significance of this phenomenon also remains unknown.

\section{Mutations of the FSH $\beta$-subunit gene}

The only mutation in the common $\alpha$-subunit gene so far described is a Glu56Ala substitution in the ectopically produced hCG of a patient with carcinoma (9). Hence, the functional consequences of a pituitary $\alpha$-subunit mutation remain unknown. Since the knock-out mouse model of the common $\alpha$-subunit gene is viable (10), it is possible that a similar human mutation could be detected. Such an individual would have severe hypothyroidism at birth and later on lack of pubertal development and infertility. Since only the homozygote of this loss-of-function mutation would apparently be affected, the condition should be extremely rare.

Four cases of inactivating mutation of the $\mathrm{FSH} \beta$ gene have so far been characterized at the molecular level
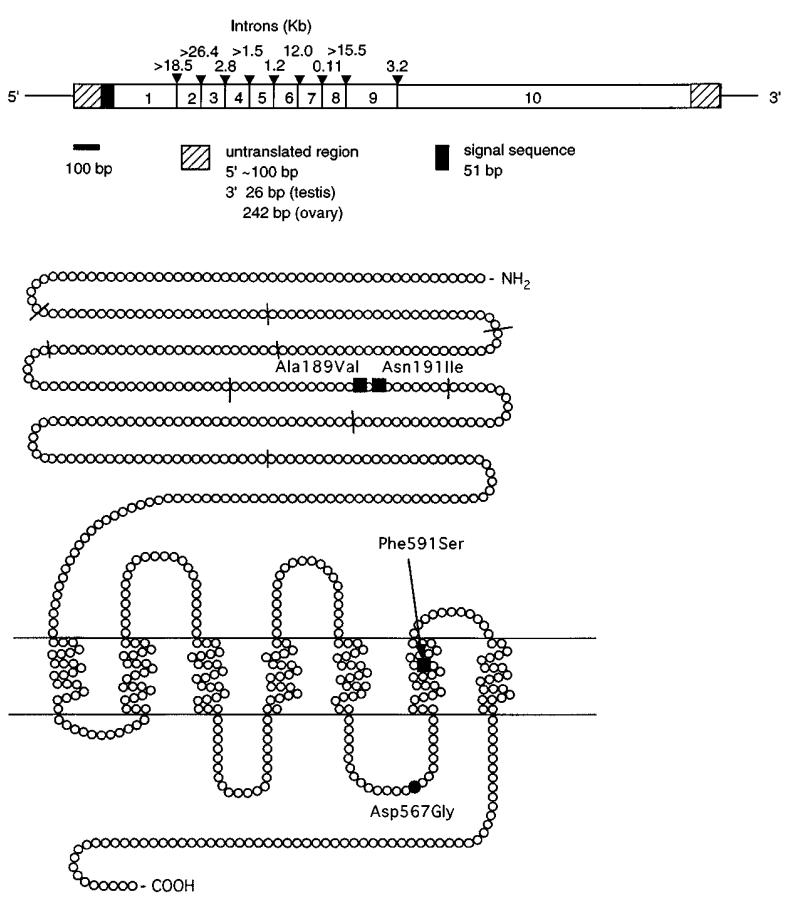

Figure 2 Schematic representation of the gene (upper panel) and protein (lower panel) structures of the FSHR. The symbols $\mathbf{\square}$ and in the lower panel mark the positions of the inactivating and activating mutations respectively $(15,17,36,47)$.

(Table 1). The first mutation reported was a $2 \mathrm{bp}$ deletion in codon 61 (Val61X) of the $\mathrm{FSH} \beta$ gene in a woman suffering from primary amenorrhea and infertility (11). The mutation gave rise to a completely altered amino acid sequence between codons 61 and 86 of the $\mathrm{FSH} \beta$ chain, which was followed by a premature stop codon, and lack of translation of amino acids 87 to 111. Consequently, the translated $\mathrm{FSH} \beta$ protein was truncated and unable to couple with the $\alpha$-subunit to form bioactive FSH $\alpha / \beta$ dimers. The affected woman apparently had normal adrenarche, but no menarche or telarche. Treatment of this patient with exogenous FSH resulted in follicular maturation, ovulation and successful pregnancy. Her mother, a heterozygote for the mutation, had suffered from menstrual irregularity and infertility, but these symptoms were apparently unrelated to her heterozygocity for the observed mutation, since the heterozygous relatives of other similar patients (see below) had no symptoms.

The second case of inactivating mutation of the $\mathrm{FSH} \beta$ gene (13) was also a female, with similar phenotype, i.e. primary amenorrhea and poorly developed secondary sex characteristics (Table 1). She had undetectable serum FSH and estradiol, high LH, and absent FSH response to the GnRH stimulation test. Upon DNA sequencing, she appeared to be a compound heterozygote for two mutations in the $\mathrm{FSH} \beta$ subunit gene. One was the same as that described by Matthews et al. (11), 
Table 1 Currently known mutations with phenotypic expression in the $\mathrm{FSH} \beta$ subunit and FSHR genes.

\begin{tabular}{|c|c|c|c|c|c|c|c|}
\hline \multirow[b]{2}{*}{ Gene } & \multirow[b]{2}{*}{ Mutation } & \multirow[b]{2}{*}{ Type } & \multirow{2}{*}{$\begin{array}{l}\text { Amino acid } \\
\text { change }\end{array}$} & \multicolumn{2}{|c|}{ Alteration in: } & \multirow[b]{2}{*}{ Phenotype } & \multirow[b]{2}{*}{ Reference } \\
\hline & & & & Bioactivity & Immunoreactivity & & \\
\hline \multirow[t]{4}{*}{$\mathrm{FSH} \beta$} & $\mathrm{GTG} \rightarrow \mathrm{GXX}$ & $\begin{array}{l}2 \text { bp deletion/premature } \\
\text { STOP codon }\end{array}$ & $\begin{array}{l}\text { Val61X } \\
\text { STOP87 }\end{array}$ & Absent & Absent & $\begin{array}{l}\text { Primary amenorrhea, } \\
\text { sexual infantilism }\end{array}$ & 11,12 \\
\hline & $\mathrm{GTG} \rightarrow \mathrm{GXX}$ & $\begin{array}{l}\text { Compound heterozygote: } \\
2 \text { bp deletion/premature }\end{array}$ & $\begin{array}{l}\text { Val61X } \\
\text { STOP87 }\end{array}$ & Absent & Absent & As above & 13 \\
\hline & $\mathrm{TGT} \rightarrow \mathrm{GGT}$ & $\begin{array}{l}\text { STOP codon } \\
+ \text { point mutation }\end{array}$ & Cys51Gly & & & & \\
\hline & $\mathrm{TGT} \rightarrow \mathrm{CGT}$ & Point mutation & Cys82Arg & Absent & Absent & Azoospermia & 14 \\
\hline \multirow[t]{2}{*}{ FSHR } & $\mathrm{GCA} \rightarrow \mathrm{GTA}$ & Point mutation & Ala189Val & Inactivating & & $\begin{array}{l}\text { Hypergonadotropic } \\
\text { ovarian failure, } \\
\text { impairment of } \\
\text { spermatogenesis }\end{array}$ & $\begin{array}{l}15 \\
16\end{array}$ \\
\hline & $\mathrm{GAC} \rightarrow \mathrm{GGC}$ & Point mutation & Asp567Gly & Activating & & $\begin{array}{l}\text { Spermatogenesis in } \\
\text { the absence of FSH }\end{array}$ & 17 \\
\hline
\end{tabular}

and the other was a missense mutation that changed a cysteine (TGT) to glycine (GGT) at codon 51. Cells transfected with the FSHR gene mutated at codon 51 failed to produced immunoreactive $\mathrm{FSH}$, apparently because of loss of a cysteine critical for proper disulfide bonds, and synthesis and secretion of the hormone. No symptoms were found in the relatives heterozygous for either of the two $\mathrm{FSH} \beta$ mutations, suggesting that one intact $\mathrm{FSH} \beta$ gene was sufficient to maintain functional FSH secretion.

In addition, there are several earlier reports on isolated FSH deficiency in men and women, but their genetic analysis was not possible at the time of most of these reports $(18-24)$. In one patient, FSH deficiency was reported to be due to circulating antibodies to this hormone (25). However, the molecular pathogenesis of FSH deficiency in this Israeli woman was recently 're-revisited' (12), and it was found to be due to the same homozygous 2 bp deletion as that detected by Matthews et al. (11) in an Italian woman.

The most recently reported mutation of the $\mathrm{FSH} \beta$ gene is still in the form of a preliminary communication in a Nordic clinical chemistry journal (14). It was found in a 32-year-old man with azoospermia, with normal puberty but selective absence of FSH. The LHtestosterone axis of the patient was apparently normal. He was unsuccessfully treated with recombinant human (rh) FSH. Genetic analysis demonstrated a T to $\mathrm{C}$ transition in codon 82 (TGT to CGT) of the FSH $\beta$ gene, predicting a cysteine to arginine mutation. Although the functional consequences of the mutation on FSH synthesis and action at the molecular level have not yet been reported, the elimination of a cysteine is suggestive of disturbances in the disulfide bond formation, with incorrect tertiary structure formation upon the synthesis and secretion of FSH molecules.

In accordance with the most recent case reported, isolated FSH deficiency has previously been reported in men with variable degrees of oligoasthenoteratozoospermia, and normal testosterone production and virilization (18-23), although FSH deficiency with normal fertility has also been reported $(19,20)$. Hence, these reports have not clarified the contentious question about the role of FSH in adult testicular function. The situation with the affected females is clearer, since arrest of follicular maturation has been found in all cases lacking FSH action.

\section{Mutations of the FSH receptor gene}

\section{Activating and inactivating mutations of the gonadotropin receptor genes}

Mutations leading to either constitutively activated or inactivated forms of the receptor were first discovered with TSHR, and soon thereafter with LHR (for recent reviews, see refs 26-28). The mutations explain certain pathologies in the thyroid gland and gonadal function. In the former, constitutive activation of the TSHR brings about toxic adenomas and hyperplasia, and inactivating mutations cause hypothyroidism. In gonads, the malelimited familial gonadotropin-independent form of precocious puberty (testotoxicosis) has been found to be due to a number of constitutively activating point mutations of the LHR gene. Inactivating mutations of the LHR gene cause male pseudohermaphroditism with Leydig cell hypoplasia, and in females amenorrhea and infertility due to anovulation.

\section{An inactivating mutation of the FSHR; hypergonadotropic ovarian failure and variable impairment of spermatogenesis}

We recently discovered an inactivating mutation of the FSHR gene in connection with hypergonadotropic ovarian failure (HOF) (15), a condition often termed 
the 'resistant ovary syndrome' (29). The study was initiated by a population based investigation (30), where a total of 75 such patients were identified in Finland. Segregation analysis confirmed the recessive mode of inheritance of the disease, as well as the existence of several kindreds with two or more affected sisters. Genealogical studies showed a clear-cut founder effect in an isolated subpopulation of the country.

A systematic search for linkage was thereafter carried out in the multiplex families, and a locus for the ovarian failure related to HOF was mapped to chromosome $2 \mathrm{p}$, with a maximum lod score of 4.71 with chromosome 2 p-specific markers. Two particularly interesting genes with respect to gonadal function were localized to this chromosome, i.e. those of FSHR (31) and LHR (32). Inactivating mutation in either gene could potentially cause failure of ovarian function. However, the critical role of FSH in the early events of ovarian development, including follicular development and maturation, as well as the absence of pseudohermaphroditism in the affected families (LHR defect would have caused such a phenotype, ref. 28), suggested an FSHR mutation as a more likely explanation for the syndrome.

The majority of mutations so far detected in the TSHR and LHR genes occur in the transmembrane domain, in particular in or near the sixth transmembrane loop (26-28). We therefore first searched for a mutation in the large exon 10 encoding the corresponding domain of the FSHR. Denaturing gradient gel electrophoresis of several overlapping polymerase chain reaction (PCR) products was used. Only one polymorphism, G2039A, resulting in Asn to Ser conversion, was found in the intracellular tail of the receptor. However, it was not connected to the disease phenotype, and it apparently does not affect the receptor function (M Tena-Sempere \& I Huhtaniemi, unpublished observations). The search was continued by PCR and denaturing gradient gel electrophoresis of the first 9 exons. It was also possible to amplify mRNA of the FSHR gene by using reverse transcriptase PCR and RNA isolated from white blood cells as template, a phenomenon termed illegitimate transcription (33). When exons 6-9 were amplified in this way, all affected individuals were found to be homozygous for a $\mathrm{C}$ to $\mathrm{T}$ transition in position 566 of exon 7 of the FSHR gene, predicting a change of alanine 189 to valine (Fig. 2). When this mutation was studied in the multiple families, the disease phenotype segregated perfectly with the mutation. All affected individuals displaying the disease were homozygous for the mutation, and all parents that could be studied (obligatory heterozygotes) were shown to be heterozygotes.

In order to prove the role of this conserved mutation in the disease phenotype, the function of the mutated FSHR gene was studied. In cells transfected with cDNA encoding the wild-type human FSHR, rhFSH evoked a 3to 4-fold dose-dependent stimulation of cAMP production (Fig. 3). In contrast, in cells expressing the mutated

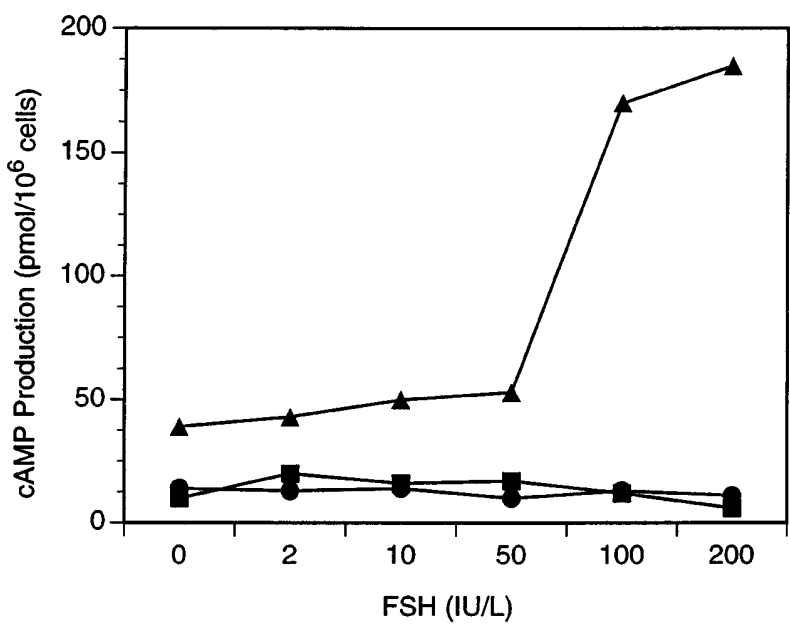

Figure $3 \mathrm{FSH}$-stimulated cAMP production of murine MSC-1 Sertoli cells transfected with the FSHR expression constructs. $\boldsymbol{\Delta}$, Wildtype; $\bullet$, mutant (Ala189Val); $\mathbf{\square}$, mock-transfected controls. Each batch of cells was co-transfected with a plasmid expressing bacterial luciferase gene under a powerful viral promoter, and cAMP production was equalized to a constant amount of luciferase expression and calculated per $10^{6}$ cells after a $3 \mathrm{~h}$ incubation. From ref. 15 with permission.

FSHR, no stimulation of cAMP by rhFSH could be detected. In accordance, the cells expressing the mutant receptor bound ${ }^{125}$ I-labeled rhFSH at only $3 \%$ of that measured in cells expressing the wild-type FSHR. The affinity of binding $\left(K_{\mathrm{a}}\right)$ was in both cases similar $((4.8-$ $6.7) \times 10^{9}$ liter $/ \mathrm{mol}$ ) and in good agreement with the affinity of human testicular FSHR (34). We have recently observed that the mutation mainly affects the folding and trafficking of the receptor protein to the cell membrane (A Rannikko, K Aittomäki, P Pakarinen \& I Huhtaniemi, unpublished observations).

Many of the HOF probands originated from a geographically defined subpopulation in north-eastern Finland. The minimum frequency of HOF in females in the whole country was calculated as 1 in 8300 . According to our preliminary estimations (15), about $40 \%$ of the HOF cases in Finland are due to the $566 \mathrm{C} \mathrm{T}$ point mutation of the FSHR gene. After the discovery of the FSHR mutation, Aittomäki et al. (35) compared the clinical features of the original HOF patients with and without the mutation. Both groups had amenorrhea with variable development of secondary sex characteristics, and high serum levels of gonadotropins. In contrast, histological examination of ovarian biopsy samples revealed the presence of follicles in all the patients studied with the receptor defect, whereas only one of four of those with unknown etiology had follicles. Hence, whereas the receptor defect causes specific arrest of follicular maturation, most of the remaining patients with HOF have true ovarian dysgenesis. Because the $566 \mathrm{C}$ T mutation of the FSHR has not been reported in other populations since our original publication in 
1995 (15), it is possible that it is absent or very rare elsewhere, and thus belongs to Finnish disease heritage. In fact, we have not been able to find this mutation in HOF patients from other populations, nor have we discovered carriers of this mutation upon DNA screening of other populations ( $\mathrm{M}$ Jiang, $\mathrm{K}$ Aittomäki, $\mathrm{P}$ Pakarinen \& I Huhtaniemi, unpublished observations). In accordance, an inactivating heterozygous Asn191Ile mutation was recently described from Germany in a healthy woman (36). Homozygocity for this mutation would probably cause the HOF phenotype.

In the affected families, there were also males homozygous for the $566 \mathrm{C} \mathrm{T}$ mutation. The phenotype of these men was of particular interest considering the uncertainty about the role of FSH in male reproductive functions (37). We recently completed a clinical study of five homozygous brothers of affected females (16) (Tables 1 and 2). All the men were normally masculinized, but had variable reduction of testicular size (4$16 \mathrm{ml}$ ). Their sperm counts ranged from normal to severe oligozoospermia $\left((0.1-42) \times 10^{6} / \mathrm{ml}\right)$, but, conspicuously, none was azoospermic. In contrast with their affected sisters, not all the men were infertile; two had two children each. As expected, their serum FSH was moderately elevated (15-40 IU/l) and inhibin B was low. Serum LH was normal to mildly elevated, but the level of testosterone was normal in all the men (Table 2). The results of this study allowed the conclusion that FSH is needed in the male to stimulate pubertal proliferation of Sertoli cells, which is an important determinant of final testicular size. It is also needed for maintenance of quantitatively normal spermatogenesis, but this process per se does not need FSH. The normal high intratesticular testosterone concentration probably compensates for the lack of FSH action in men with the inactivating FSHR mutation. Because of the mild phenotypic alterations, they could only be identified on the basis of their relationship with the women with the receptor defect and a clear phenotype.

In addition to HOF, delayed puberty, premature ovarian failure and idiopathic infertility have been suggested to be caused by aberrant FSHR function. However, Whitney et al. (38) were unable to detect causative mutations in the FSHR gene in a group of 21 women with premature ovarian failure. Considering the many activating and inactivating mutations that have recently been discovered in the LHR gene, it is likely that a number of other FSHR mutations will also be found. The spectrum of reproductive pathologies caused by such mutations is also likely to expand.

It is of interest to compare the phenotypic effects of the inactivating FSHR mutation with those of the documented cases of selective FSH deficiency. The phenotype of the FSH-deficient women resembles HOF with primary amenorrhea and infertility, but they can be treated with FSH with resulting successful pregnancy $(11,25)$. No means are yet available for stimulating follicular maturation in FSHR-deficient women despite the abundance of primordial follicles in their ovaries. Both the FSH-deficient men and those with the FSHR defect appear to have variable degrees of spermatogenic arrest, but normal fertility is also possible. Both groups invariably have normal testosterone production and normal virilization $(14,16,19,20)$. In conclusion, both the FSH ligand and receptor defects give almost identical phenotypes, indicating that FSH is more critical for female than male fertility. This knowledge is useful for the development of novel contraception strategies. In the female, blockade of FSH activity brings about effective contraception, whereas in men such strategies are likely to fail because of the wide variability in spermatogenic suppression in men devoid of FSH action.

\section{An activating mutation of the FSH receptor gene, sustaining autonomous spermatogenesis in a hypophysectomized male}

Gromoll et al. (17) found recently a 28-year-old male who 8 years earlier had been hypophysectomized and treated with radiotherapy because of a pituitary chromophobe adenoma. He had no residual pituitary function and received replacement therapy with glucocorticoids, thyroxine and testosterone. His circulating gonadotropin levels were below the level of detection $(<0.5 \mathrm{IU} / \mathrm{l})$, as measured by sensitive immunometric and in vitro bioassay methods. Serum testosterone concentration was within the normal male range because of the replacement therapy. Despite the disease history, the testis volume of the patient was in the upper normal range and spermatogenesis appeared to be

Table 2 Testis size, sperm count and some serum hormone levels in five men homozygous for the inactivating Ala189Val mutation of the FSHR gene $(15,16)$.

\begin{tabular}{|c|c|c|c|c|c|c|}
\hline Subject & $\begin{array}{c}\text { Testis size }(\mathrm{ml}) \\
\quad \text { (right/left) }\end{array}$ & $\begin{array}{c}\text { Sperm count } \\
\left(10^{6} / \mathrm{ml}\right)\end{array}$ & $\begin{array}{l}\text { FSH } \\
(\mathrm{IU} / \mathrm{I})\end{array}$ & $\begin{array}{l}\text { LH } \\
(\mathrm{IU} / \mathrm{I})\end{array}$ & $\begin{array}{c}\text { Testosterone } \\
(\mathrm{nmol} / \mathrm{l})\end{array}$ & $\underset{(\mathrm{ng} / \mathrm{l})}{\operatorname{Inhibin} \mathrm{B}}$ \\
\hline 1 & $4.0 / 4.0$ & $<0.1$ & 23.5 & 16.6 & 14.5 & $<15$ \\
\hline 2 & $15.0 / 13.8$ & 5.6 & 12.5 & 5.6 & 8.8 & 33 \\
\hline 3 & $13.5 / 15.8$ & $<0.1$ & 15.1 & 4.2 & 15.8 & 62 \\
\hline 4 & 8.0/8.0 & $<1.0$ & 20.6 & 16.2 & 26.2 & 54 \\
\hline 5 & $8.0 / 6.8$ & 42 & 39.6 & 11.1 & 14.7 & 53 \\
\hline Reference range & & $>20$ & $1-10.5$ & $1-8.4$ & $8.2-34.6$ & $76-447$ \\
\hline
\end{tabular}


normal, with only slightly subnormal morphology and motility. During testosterone replacement, four pregnancies were induced, resulting in births of three healthy boys.

This led the investigators to the hypothesis that the signal-transduction pathway of FSH had to be autonomously activated in the patient. Although there are studies, in rodents in particular, indicating that testosterone alone can sustain, and even initiate, spermatogenesis $(39,40)$, clinical evidence shows that fertility cannot be achieved in hypogonadal males with testosterone alone (41). Hence, it was logical to assume that the patient has some residual FSH activity, possibly because of a constitutively activated FSHR. Such an hypothesis is reasonable in the light of the numerous activating mutations that have recently been documented for LHR and TSHR (26-28).

Exon 10 of the patient's FSHR gene was amplified by PCR from genomic DNA and subjected to single-strand conformation polymorphism analysis and sequencing. A heterozygous A to $G$ mutation was observed in nucleotide 1700 of the gene, resulting in an asparagine to glycine transition in codon 567 of the third intracytoplasmic loop of the transmembrane region (Fig. 2). Interestingly, the same location, and especially the neighboring sixth transmembrane domain, has been identified as a 'hot spot' for activating and inactivating mutations of LHR and TSHR (26-28). When the wild-type and mutated receptor cDNAs were transfected into $\operatorname{COS} 7$ cells, the latter consistently resulted in about 50\% higher basal cAMP production of the cells. The FSH-stimulated rates of cAMP production were similar after both transfections.

These findings are consistent with partial constitutive activation of the mutated FSHR in the absence of ligand, and provide an explanation for the sustained spermatogenesis of the patient undergoing testosterone replacement therapy but without any circulating FSH. It is noteworthy that spermatogenesis of the patient was also sustained when testosterone replacement therapy was interrupted, which provides further evidence for the critical role of the activating FSHR mutation in the maintenance of spermatogenesis. The only discordant finding in this interesting case was the persistence of rather high (at least $5 \mathrm{nmol} / \mathrm{l}$ ) plasma testosterone levels in the absence of replacement therapy. These are 5- to 10-fold higher than those of castrated men, and the control of this testicular activity in the hypophysectomized man remains an open question. The contribution of the apparently high intratesticular androgen level of the subject to the maintenance of spermatogenesis, in conjunction with the constitutively activated FSHR, remains obscure. Moreover, it remains unclear whether the pathogenesis of the subject's pituitary tumor was somehow connected with the aberrant testicular function.

In accordance with this case, FSH alone can sustain spermatogenesis in monkeys rendered pharmacologically hypogonadotropic by GnRH antagonist therapy
(42). In contrast, in rodents it seems to be easier to maintain spermatogenesis with testosterone alone (37, 39-41). There is also a report that long-term hCG treatment alone, in the absence of $\mathrm{FSH}$, can initiate spermatogenesis in hypogonadotropic men (43). Therefore, depending on the species, there are data both for and against the mandatory role of FSH, and even of testosterone, in the maintenance of spermatogenesis. Apparently the two hormones are synergistic stimulators of this process, but in the absence of one (at least FSH) the function of the other, probably in concert with other hormones and paracrine regulators, can maintain spermatogenesis. Quantitatively and qualitatively normal spermatogenesis, however, is dependent on the combined action of testosterone and FSH.

The previous hypophysectomy of the patient of Gromoll et al. (17) enabled the identification of the activating FSHR mutation, and it is questionable whether this type of FSH mutation would cause any phenotypic changes in otherwise healthy men. Chronic FSH hyperstimulation at a prepubertal age would potentially lead to increased testis size (which was found in this patient), but such an association was ruled out in 13 men with megalotestes (17). It is also possible that the phenotypic change is sex-limited in the same way as the activating LHR mutation, which only alters the phenotype in men in the form of testotoxicosis (see above). A female phenotype for this mutation has not yet been characterized. It could cause disturbances of sexual maturation or cyclic ovarian function. Constant FSH stimulation could also lead to accelerated follicular 'consumption' and premature ovarian failure, but no FSHR mutations were discovered in such patients (38).

\section{Ovarian sex cord stromal tumors; controversial findings on involvement of mutated FSHR}

Sex cord stromal tumors, accounting for $5-10 \%$ of ovarian malignancies, are notable for their endocrine activity (for a review, see ref. 44). Their major subtypes include granulosa cell tumors, thecomas, Sertoli and Leydig cell tumors, and others with varying combinations of stromal tissue; granulosa cell tumors are the most common ones. Since many of these tumors have functional FSHR (45) and are estrogenic, FSH may play a key role in their formation and growth. Because the tumors secrete inhibin and other peptides of the same gene family, and the patients have low FSH levels (46), it is possible that an activating mutation of the FSHR could explain their pathogenesis. Kotlar et al. (47) recently published a study in which a group of ovarian sex cord tumors, small cell carcinomas and control DNA specimens were screened for mutations in the transmembrane domain of the FSHR, the most likely site of mutations. A heterozygous $\mathrm{T}$ to $\mathrm{C}$ mutation was found in nucleotide 1777 converting codon 591 from phenylalanine to serine. This mutation was found in 
nine of $13(69 \%)$ of the sex cord tumors and in two of three ovarian small cell carcinomas, but in none of the control DNA specimens. A recombinant form of the mutant receptor was found to be unable to stimulate cAMP production. It was assumed that the mutation plays a role in formation of the ovarian tumors. Since the tumor DNA was extracted from archival paraffinembedded tissue specimens, the possibilities of studying the patients further were limited. In the absence of normal tissue from the patients, it remains unclear whether the mutation was acquired somatically or was present in the germline. Surprisingly, the mutation appeared to be of the loss-of-function type, and therefore it is hard to rationalize how such a mutation in heterozygous form could be oncogenic. It is possible that the detected mutation is an indicator of multiple, as yet unidentified, mutations in the tumors, some of which could be responsible for the oncogenic alterations.

A similar group of ovarian granulosa cell tumors was recently studied for FSHR mutations by another group (48). Quite surprisingly, they could not detect the above or any other FSHR mutations in a total of 15 granulosa cell tumors. The discrepancy between these two reports is difficult to reconcile because of apparently similar tissue material and analytical methods. A possible explanation is that the samples analyzed represent different subgroups of granulosa cell tumors, which could thus be classified according to the presence of the FSHR mutation. In any case, the final significance of FSHR mutations in ovarian sex cord stromal tumors remains open.

\section{Animal models for disturbed FSH action}

Two gene knock-out models in particular are of interest with regard to FSH action. One is the targeted disruption of the common $\alpha$-subunit gene (10). Since the synthesis of all three pituitary glycoprotein hormones is inhibited in this model because of the absence of the common $\alpha$-subunit, the null mutant mice were hypothyroid and hypogonadal. With respect to the hypogonadism, their lack of postnatal sexual development and infertility were expected. However, the sexual differentiation of these mice seemed to proceed normally during the fetal period. At birth, the mutant and normal mice were phenotypically indistinguishable; the differentiation of sexual organs was complete in both sexes. However, the testis size of the mutant males remained small and there was no onset of spermatogenesis. Likewise, the ovaries remained small, and follicular maturation was restricted to the preantral stage. The main message of this model with respect to gonadal function is that gonadotropins are not necessary for prenatal sexual differentiation or for follicular maturation until the preantral stage. These findings are in good agreement with those obtained for known human mutations for gonadotropins, TSH and their respective receptors.
The group of Matzuk recently achieved targeted disruption of the mouse FSH $\beta$ gene (49). Interestingly, the phenotype of the null mutant mice was practically identical with that of the inactivating FSHR mutation: the females were infertile and displayed arrested follicular maturation, whereas the males were fertile but had reduced testicular size and somewhat impaired spermatogenesis. The findings with this model, together with the human FSH and FSHR mutations, are corroborated by the findings that androgen treatment alone can initiate and maintain spermatogenesis in the hypogonadotropic hpg mutant mouse (39). Hence, all the recent clinical and experimental data on inactivated FSH secretion or action provide strong evidence that FSH is not essential for the pubertal initiation of spermatogenesis, and that this gonadotropin is more important for female than male fertility.

\section{Conclusions}

Although FSH and FSHR mutations are extremely rare, they are very informative as regards the role of FSH in the regulation of ontogeny and functions of the ovary and testis in the adult. The reported human mutations and knock-out mice have displayed surprisingly similar phenotypes, which is encouraging with respect to the relevance of the expensive and labor-intensive knockout models. For FSH function in particular, the novel information has been very elucidating. It has unequivocally demonstrated that the early phases of follicular maturation (up to the preantral stage) are independent of $\mathrm{FSH}$, but that this gonadotropin is absolutely necessary for the final stages of this maturation process. Consequently, women lacking FSH action are obligatorily infertile. In men, the respective lack of FSH action seems only to impair fertility without necessarily making them completely infertile. Hence, spermatogenesis is possible without the action of FSH, although this hormone is needed for the maintenance of qualitatively and quantitatively normal spermatogenesis. One practical message from these studies is important in the field of contraceptive development. Although the inhibition of FSH can effectively prevent female fertility, male contraception based on this principle is apparently not a possibility. Patients with inactivating mutations of FSH can be effectively treated with exogenous FSH, whereas no form of treatment is at the moment available for those suffering from inactivation of the FSHR. Animal models for such conditions through targeted mutagenesis of the FSHR might be useful. In them, attempts could be made to develop non-gonadotropic replacement therapies for bypassing the blockage of follicular maturation and for improvement of spermatogenesis.

\section{References}

1 Bousfield GR, Perry WM \& Ward DN. Gonadotropin chemistry and biosynthesis. In The Physiology of Reproduction, edn 2, 
pp 1749-1792. Eds E Knobil \& JD Neill. New York: Raven Press 1994.

2 Moyle WR \& Campbell RK. Gonadotropins. In Reproductive Endocrinology. Surgery, and Technology, pp 683-724. Eds EY Adashi, JA Rock \& Z Rosenwaks. Philadalphia: Lippincott-Raven, 1996

3 Gharib SD, Wierman ME, Shupnik MA \& Chin WW. Molecular biology of the pituitary gonadotropins. Endocrine Reviews 199011 177-199.

4 Ulloa-Aguirre A, Midgley AR, Jr, Beitins IZ \& Padmanabhan V. Follicle-stimulating isohormones: characterization and physiological relevance. Endocrine Reviews 199516 765-787.

5 Griswold MD. Actions of FSH on mammalian Sertoli cells. In The Sertoli Cell, pp 493-508. Eds LD Russell \& MD Griswold. Clearwater: Cache River Press, 1993.

6 Simoni M, Gromoll M \& Nieschlag E. The follicle-stimulating hormone receptor: biochemistry, molecular biology, physiology, and pathophysiology. Endocrine Reviews 199718 739-773.

7 Kelton CA, Cheng SVY, Nugent NP, Schweikhardt RL, Rosenthal JL, Overton SA et al. The cloning of the human follicle stimulating hormone receptor and its expression in COS-7, CHO, and Y-1 cells. Molecular and Cellular Endocrinology 199289141 151.

8 Gromoll J, Pekel E \& Nieschlag E. The structure and organization of the human follicle-stimulating hormone receptor (FSHR) gene. Genomics $199635308-311$.

9 Nishimura R, Shin J, Ji I, Middaugh CR, Kruggel W, Lewis RV et al. A single amino acid substitution in an ectopic $\alpha$ subunit of a human choriogonadotropin. Journal of Biological Chemistry 1986 261 10475-10477.

10 Kendall SK, Samuelson LC, Saunders TL, Wood RI \& Camper SA. Targeted disruption of the pituitary glycoprotein hormone $\alpha$ subunit produces hypogonadal and hypothyroid mice. Genes and Development 19959 2007-2019.

11 Matthews $\mathrm{CH}$, Borgato S, Beck-Peccoz P, Adams M, Tone, Gambino G et al. Primary amenorrhoea and infertility due to a mutation in the $\beta$-subunit of follicle-stimulating hormone. Nature Genetics 19935 83-86.

12 Matthews C \& Chatterjee VK. Isolated deficiency of folliclestimulating hormone re-revisited. New England Journal of Medicine 1997337642

13 Layman LC, Lee E-J, Peak DB, Namnoum AB, Vu KV, van Lingen B et al. Delayed puberty and hypogonadism caused by mutations in the follicle-stimulating hormone $\beta$-subunit gene. New England Journal of Medicine $1997337607-611$.

14 Lindstedt G, Ernest I, Nyström E \& Janson PO. Fall av manlig infertilitet. Klinisk Kemi i Norden 19973 81-87.

15 Aittomäki K, Dieguez Lucena JL, Pakarinen P, Sistonen P, Tapanainen J, Gromoll J et al. Mutation in the follicle-stimulating hormone receptor gene causes hereditary hypergonadotropic ovarian failure. Cell $199582959-968$.

16 Tapanainen JS, Aittomäki K, Jiang M, Vaskivuo T \& Huhtaniemi IT. Men homozygous for an inactivating mutation of the folliclestimulating hormone (FSH) receptor gene present variable suppression of spermatogenesis and fertility. Nature Genetics $199715205-206$

17 Gromoll J, Simoni M \& Nieschlag E. An activating mutation of the follicle-stimulating hormone receptor autonomously sustains spermatogenesis in a hypophysectomized man. Journal of Clinical Endocrinology and Metabolism 199681 1367-1370.

18 Rabin D, Spitz I, Bercovici B, Bell J, Laufer A, Benveniste R et al. Isolated deficiency of follicle-stimulating hormone: clinical and laboratory features. New England Journal of Medicine 1972287 1313-1317.

19 Maroulis GB, Parlow AF \& Marshall JR. Isolated folliclestimulating hormone deficiency in man. Fertility and Sterility 197728 818-822.

20 Hägg E, Tollin C \& Bergman B. Isolated FSH deficiency in a male: a case report. Scandinavian Journal of Urology and Nephrology 1978 $12287-289$
21 McConnon J, Killinger D, Gracey W \& Ghany F. Clomiphene in treatment of male infertility due to isolated follicle-stimulating hormone deficiency. Lancet 19792 525-526.

22 Mozaffarian GA, Higley M \& Paulsen CA. Clinical studies in an adult male patient with isolated follicle-stimulating hormone (FSH) deficiency. Journal of Andrology 19834 393-398.

23 Al-Ansari AA-K, Khalil TH, Kelani Y \& Mortimer CH. Isolated follicle-stimulating hormone deficiency in men: successful longterm gonadotropin therapy. Fertility and Sterility $198442618-$ 626.

24 Diez JJ, Iglesias P, Sastre J, Salvador J, Gomez-Pan A, Otero I \& Granizo V. Isolated deficiency of follicle-stimulating hormone in man: a case report and literature review. International Journal of Fertility and Menopausal Studies 199439 26-31.

25 Rabinowitz D, Benveniste R, Lindner J, Lober D \& Danniell J. Isolated FSH deficiency revisited: ovulation and conception in presence of circulating antibody to follicle-stimulating hormone. New England Journal of Medicine 1979300 126-128.

26 Van Sande J, Parma J, Tonacchera M, Swillens S, Dumont J \& Vassart G. Somatic and germline mutations of the TSH receptor gene in thyroid diseases. Journal of Clinical Endocrinology and Metabolism 199580 2577-2585.

27 Spiegel AM. Mutations in G proteins and G protein-coupled receptors in endocrine disease. Journal of Clinical Endocrinology and Metabolism 199681 2434-2442.

28 Themmen APN, Martens JWM \& Brunner HG. Gonadotropin receptor mutations. Journal of Endocrinology 1997153 179-183.

29 Wentz AC. Resistant ovary syndrome. In Reproductive Endocrinology, Surgery, and Technology, pp 1385-1392. Eds EY Adashi, JA Rock \& Z Rosenwaks. Philadelphia: Lippincott-Raven, 1996.

30 Aittomäki K. The genetics of XX gonadal dysgenesis. American Journal of Human Genetics 199454 844-851.

31 Rousseau-Merck MF, Atger M, Loosfelt H, Milgrom E \& Berger R. The chromosomal localization of the human follicle-stimulating hormone receptor gene (FSHR) on $2 \mathrm{p} 21-2 \mathrm{p} 15$ is similar to that of the luteinizing hormone receptor gene. Genomics 199315 222-224.

32 Rousseau-Merck MF, Misrahi M, Atger M, Loosfelt H, Milgrom E \& Berger R. Localization of the human LH (luteinizing hormone) receptor gene to chromosome 2p21. Cytogenetics and Cell Genetics $19905477-79$.

33 Chelly J, Concordet J-P, Kaplan J-C \& Kahn A. Illegitimate transcription: transcription of any gene in any cell type. Proceedings of the National Academy of Sciences of the USA 1989 $862617-2621$.

34 Wahlström T, Huhtaniemi I, Hovatta O \& Seppälä M. Localization of luteinizing hormone, follicle-stimulating hormone, prolactin, and their receptors in human and rat testis using immunohistochemistry and radioreceptor assay. Journal of Clinical Endocrinology and Metabolism 198357 825-830.

35 Aittomäki K, Herva R, Stenman U-H, Juntunen K, Ylöstalo P, Hovatta $\mathrm{O}$ et al. Clinical features of primary ovarian failure caused by a point mutation in the follicle-stimulating hormone receptor gene. Journal of Clinical Endocrinology and Metabolism 199681 $3722-3726$

36 Gromoll J, Simoni M, Nordhoff V, Behre HM, De Geyter C \& Nieschlag E. Functional and clinical consequences of mutations in the FSH receptor. Molecular and Cellular Endocrinology 1996 $125177-182$.

37 Zirkin BR, Awoniyi C, Griswold MD \& Sharpe RM. Is FSH required for adult spermatogenesis? Journal of Andrology 199415 273-240.

38 Whitney EA, Layman LC, Chan PJ, Lee A, Peak DB \& McDonough PG. The follicle-stimulating hormone receptor gene is polymorphic in premature ovarian failure and normal controls. Fertility and Sterility 199564 518-524.

39 Singh J, O'Neill C \& Handelsman DJ. Induction of spermatogenesis by androgens in gonadotropin-deficient (hpg) mice. Endocrinology $19551365311-5321$.

40 Awoniyi CA, Zirkin BR, Chandrachekar V \& Schlaff WD. Endogenously administered testosterone maintains spermatogenesis 
quantitatively in adult rats actively immunized against gonadotropin-releasing hormone. Endocrinology $19921303283-3288$.

41 Weinbauer GF \& Nieschlag E. Hormonal regulation of spermatogenesis. In Molecular Biology of the Male Reproductive System, pp 99-142. Ed D de Kretser. New York: Academic Press, 1993.

42 Weinbauer GF, Behre HM, Fingscheidt U \& Nieschlag E Human follicle-stimulating hormone exerts a stimulatory effect on spermatogenesis, testicular size and serum inhibin levels in the gonadotropin-releasing hormone antagonist-treated, non human primate (Macaca fascicularis). Endocrinology 1991129 1831-1839.

43 Vicari E, Mongioi A, Calogero AE, Moncada ML, Sidoti G, Polosa P et al. Therapy with human chorionic gonadotrophin alone induces spermatogenesis in men with isolated hypogonadotrophic hypogonadism: long-term follow-up. International Journal of Andrology 199215 320-329.

44 Young RH \& Scully RE. Endocrine tumors of the ovary. Current Topics in Pathology 199285 114-164.

45 Stouffer RL, Grodin MS, Davis JS \& Surwit EA. Investigation of binding sites for follicle-stimulating hormone and chorionic gonadotropin in human ovarian cancers. Journal of Clinical Endocrinology and Metabolism 198459 441-446.
46 Lappohn RE, Burger HG, Bouma J, Bangah M, Krams M \& de Brujin HW. Inhibin as a marker for granulosa cell tumors. New England Journal of Medicine 1989321 790-793.

47 Kotlar TJ, Young RH, Albanese C, Crowley WF, Jr, Scully RE \& Jameson JL. A mutation in the follicle-stimulating hormone receptor occurs frequently in human ovarian sex cord tumors. Journal of Clinical Endocrinology and Metabolism 199782 1020-1026.

48 Fuller PJ, Verity K, Shan Y, Mamers P, Jobling T \& Burger HG. No evidence of a role for mutations or polymorphisms of the FSH receptor in ovarian granulosa cell tumors. Journal of Clinical Endocrinology and Metabolism 199883 274-279.

49 Kumar TR, Wang Y, Lu N \& Matzuk MM. Follicle-stimulating hormone is required for ovarian follicular maturation but not male fertility. Nature Genetics 199715 201-204.

Received 27 January 1998

Accepted 5 February 1998 